\title{
Caffeic Acid Phenethyl Ester (CAPE) in Romanian Propolis
}

\author{
Liviu Al. MĂRGHITAȘ, Daniel DEZMIREAN, Flavius DRÂGLĂ, Otilia BOBIŞ* \\ Department of Apiculture and Sericulture, University of Agricultural Sciences and Veterinary Medicine \\ Cluj-Napoca, 3-5 Mănăştur Street, 400372 Cluj-Napoca, Romania \\ *Corresponding author, email: obobis@usamvcluj.ro
}

Bulletin UASVM Animal Science and Biotechnologies 71(2) / 2014,

Print ISSN 1843-5262; Electronic ISSN 1843-536X

DOI: $10.15835 /$ buasvmcn-asb:10557

\begin{abstract}
Propolis is an important bee product, rich in biologically active compounds. It is collected by the bees from buds and exudates of different trees and plants and it has been used since ancient times as a natural remedy or in embalming process. Caffeic acid phenethyl ester (CAPE) is one of the main medicinal components of propolis, possessing important biological activities, such as anti-bacterial, anti-oxidant anti-inflammatory and the most important anti-cancer properties. Taking into account that CAPE is an excellent compound in cancer, hepatitis and other oxidative stress diseases treatment, knowing the amount of this compound in Romanian propolis is a very challenging proposal. To identifiy and qualtify the amount of CAPE in the samples, chromatographic determinations were made according to existing method developed in APHIS Laboratory.The analyzed propolis samples show that beside different phenolic acids and flavonoiuds, Romanian propolis is also rich in CAPE. Concentrations ranging from 0.86 to $3.87 \mathrm{mgCAPE} / \mathrm{g}$ was measured and correlated with high amounts of chrysin. High concentrations of caffeic acid $(1.4 \mathrm{mg} / \mathrm{ml})$ and pinocembrin $(2.85 \mathrm{mg} / \mathrm{g})$ were also determined in the analyzed samples. HPLC analysis of propolis samples from different locations in Romania, has highlighted the fact that they contain large amounts of CAPE. This propolis may be used successfully in the treatment of various diseases, including cancer.
\end{abstract}

Keywords: CAPE, flavonoids, HPLC, propolis, polyphenols

\section{INTRODUCTION}

Propolis is a resinous beehive product, collected by honeybees from different plant sources, including poplar buds, willow, plums, coniferous or alder (Mărghitaş, 2005). It has a pleasant aromatic flavor and different colors from yellow-green to dark brown, depending on its botanical source and geographical origin.

Propolis has a long history of being used in traditional medicine dating back at least to $300 \mathrm{BC}$ and has been reported to have a broad spectrum of biological activities, including

antioxidant, antiinflammatory, antibiotic, antifungal and anticancer activities (Marcucci 1995; Kimoto et al., 1998; Bankova et al., 2000; Banskota et al., 2001; Mărghitaş et al., 2013).

Because of its large spectrum of biological activities and uses in different food supplements as well as in apitherapy, there is a renewed interest in the composition of propolis and its biological activities. As a consequence, more than 300 constituents have been identified so far from propolis, which are well described by Marcucci (1995), Bankova et al. (2000), Mărghitaş et al. (2013) in their review articles.

As a natural compound bearing polyphenolic ring, cafeic acid phenetyl ester (CAPE) (Fig. 1), is originated from a this biologically active bee product, propolis.<smiles>O=C(/C=C/c1ccc(O)c(O)c1)OCCc1ccccc1</smiles>

Fig. 1. Chemical structure of caffeic acid phenethylester (CAPE) 
It is known to have antitumoral, antiinflammatory, antineoplastic activity (Oršolic et al., 2005; Lotfy 2006; Lin et al., 2012; Markiewicz-Żukowska et al., 2012; Omene et al., 2012) and antioxidant properties to some extend.

The aim of our research was to identify and quantify the bioactive compounds from Romania propolis and to search for the specific compound (CAPE) with high antitumoral activity.

\section{MATERIALS AND METHODS}

For this experiment, thirteen samples of propolis were harvested from Transylvania Region ( 7 counties), from stationary apiaries. The samples were immediately transported to laboratory and stored at $-20^{\circ} \mathrm{C}$ until analysis. Chemical analysis as well as bioactive constituents were measured from alcoholic extracts $(1 \% \mathrm{w} / \mathrm{v})$ of each sample.

Water content was measured from grounded samples dried in the owen until constant weight. Wax analysis was measured with Soxhlet equipment following a standard method, adapted for propolis (in terms of solvent used and extraction time).

Total phenolic content and total flavonoid content were assessed following literature methods (Folin Ciocâlteu for total phenolics (Popova et al., 2004) and total flavonoid content (Nagy and Grancai, 1996; Popova et al., 2004).

Stock solutions of galangin for flavone/ flavonols and pinocembrin for flavanone/ dihydroflavonols quantification were prepared and diluted properly to construct calibration curves for total flavonoid determination. A mixture of pinocembrin and galangin $(2: 1 \mathrm{w} / \mathrm{w})$ was prepared as stock solution for total polyphenols' determination. Propolis ethanolic extracts and serial dilutions of standards were prepared identically for absorbance reading and phenols quantification.
As propolis extracts are soluble in ethanolic and hydroalcoholic solutions, reverse phase High Performance Liquid Chromatography (HPLC), has become the most commonly used chromatographic method for propolis analysis. Phenolics and flavonoids absorb in the UV-Vis range and can easily be detected with a diode array detector (DAD)(Marcucci et al., 2000; Marcucci et al., 2008). HPLC-DAD has been applied to the characterization of Romanian propolis, following a method of Garcia-Viguera et al. (1993).

\section{RESULTS AND DISCUSSION}

Total polyphenols and total flavonoid content indicates the levels of bioactive compounds present in propolis samples. As a mean of the thirteen samples we quantified $73.66 \mathrm{mg} / \mathrm{g}$ phenols and $38.96 \mathrm{mg} / \mathrm{g}$ flavonoids (Tab. 1). These amounts are in accordance with literature data, obtained both from other Romanian propolis samples (Coneac et al., 2008; Croci et al., 2009) and from other European propolis (Bankova et al., 1992; Bankova et al., 2002). We made this specification, because is is generally known that Romanian propolis have the same pattern of bioactive compounds than most of all European propolis, all of them belonging to poplar type propolis. This type of propolis is characterized by high amounts of phenolics.

Populus species are considered to be the main source of propolis, the main phenolic compounds in propolis are flavonoids, such as pinocembrin, pinobanksin, chrysin and galangin (Bankova et al., 1992; Bankova et al., 2002). In our propolis samples pinocembrin, chrysin, galangin or quercetin were found, caffeic, p- and o-coumaric, ferulic acids were about $12.5 \%$ from total polyphenols (quantification based on HPLC/DADanalyses)(Fig. 2).

Tab. 1. The content of total polyphenols and total flavonoids (mean \pm S.E. in g) of Romanian propolis samples

\begin{tabular}{llc}
\hline $\begin{array}{l}\text { Propolis samples } \\
(\mathrm{n}=13)\end{array}$ & Total polyphenols $(\mathrm{mg} / \mathrm{g})$ & Total flavonoids $(\mathrm{mg} / \mathrm{g})$ \\
\cline { 2 - 3 } & $73.66 \pm 5.2$ & $38.96 \pm 2.42$ \\
\hline
\end{tabular}




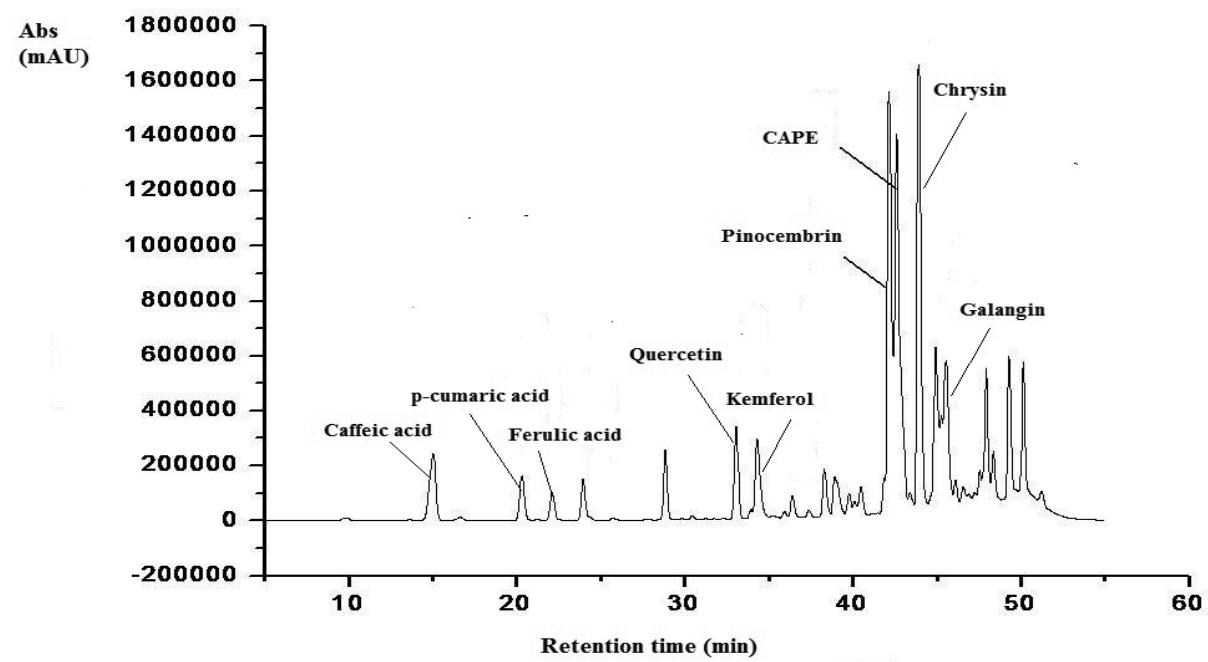

Fig. 2. Chromatogram of one propolis sample with identified phenolic compounds including caffeic acid phenetylester (CAPE)

Tab. 2. Identified compounds using HPLC analysis of propolis samples (mg/g propolis)

\begin{tabular}{llllllll}
\hline Sample & Pinocembrin & Chrysin & Galangin & Caffeic acid & p-coumaric acid & Ferulic acid & CAPE \\
\hline P1 & $2.08 \pm 0.11$ & $3.91 \pm 0.85$ & $2.66 \pm 0.15$ & $0.78 \pm 0.01$ & $0.51 \pm 0.02$ & $0.57 \pm 0.02$ & $0.87 \pm 0.02$ \\
P2 & $1.67 \pm 0.09$ & $3.06 \pm 0.45$ & $1.97 \pm 0.15$ & $0.89 \pm 0.02$ & $0.63 \pm 0.01$ & $0.19 \pm 0.01$ & $0.98 \pm 0.04$ \\
P3 & $1.00 \pm 0.08$ & $0.55 \pm 0.04$ & $0.97 \pm 0.05$ & $0.74 \pm 0.04$ & $0.87 \pm 0.00$ & $0.64 \pm 0.01$ & $0.95 \pm 0.02$ \\
P4 & $0.36 \pm 0.00$ & $1.14 \pm 0.25$ & $0.56 \pm 0.01$ & $0.58 \pm 0.03$ & $1.12 \pm 0.21$ & $0.69 \pm 0.02$ & $0.86 \pm 0.06$ \\
P5 & $0.63 \pm 0.01$ & $2.51 \pm 0.25$ & $0.60 \pm 0.02$ & $0.97 \pm 0.02$ & $1.20 \pm 0.30$ & $0.15 \pm 0.00$ & $2.26 \pm 0.25$ \\
P6 & $1.65 \pm 0.08$ & $3.44 \pm 0.42$ & $1.89 \pm 0.21$ & $1.26 \pm 0.21$ & $0.81 \pm 0.04$ & $0.34 \pm 0.01$ & $2.20 \pm 0.26$ \\
P7 & $0.49 \pm 0.01$ & $2.47 \pm 0.31$ & $0.81 \pm 0.04$ & $1.07 \pm 0.31$ & $0.84 \pm 0.06$ & $0.29 \pm 0.04$ & $2.05 \pm 0.42$ \\
P8 & $1.06 \pm 0.08$ & $2.66 \pm 0.45$ & $1.67 \pm 0.03$ & $1.49 \pm 0.20$ & $1.14 \pm 0.21$ & $0.15 \pm 0.02$ & $1.19 \pm 0.25$ \\
P9 & $0.13 \pm 0.00$ & $1.14 \pm 0.21$ & - & $0.48 \pm 0.02$ & $1.33 \pm 0.04$ & $1.98 \pm 0.04$ & $1.66 \pm 0.21$ \\
P10 & $0.15 \pm 0.00$ & $1.51 \pm 0.16$ & - & $0.84 \pm 0.01$ & $1.89 \pm 0.08$ & $1.65 \pm 0.08$ & $1.16 \pm 0.04$ \\
P11 & $0.69 \pm 0.02$ & $2.70 \pm 0.12$ & - & $0.73 \pm 0.04$ & $0.79 \pm 0.02$ & $1.06 \pm 0.04$ & $3.87 \pm 0.21$ \\
P12 & - & $0.66 \pm-.02$ & - & $0.46 \pm 0.02$ & $1.19 \pm 0.31$ & $1.59 \pm 0.08$ & $1.29 \pm 0.08$ \\
P13 & $1.72 \pm 0.06$ & $2.04 \pm 0.42$ & $1.90 \pm 0.06$ & $0.51 \pm 0.01$ & $0.50 \pm 0.04$ & $0.15 \pm 0.01$ & $2.37 \pm 0.14$ \\
\hline
\end{tabular}

Note: Results represent the mean \pm standard deviation of three replicates separately analyzed.

Tab. 3. Location and amounts of bioactive compounds identified and quantified in propolis samples, analyzed by HPLC (mg/g propolis)

\begin{tabular}{ccccc}
\hline Propolis sample & Location & CAPE & Chrysin & Caffeic acid \\
\hline P5 & Alba & $2.26 \mathrm{e}$ & $2.51 \mathrm{c}$ & $0.97 \mathrm{~h}, \mathrm{i}$ \\
P6 & Alba & $2.20 \mathrm{e}, \mathrm{f}$ & $3.44 \mathrm{c}, \mathrm{d}$ & $1.26 \mathrm{~g}$ \\
P7 & Arad & $2.05 \mathrm{f}$ & $2.47 \mathrm{c}$ & $1.07 \mathrm{~h}$ \\
P11 & Hunedoara & $3.87 \mathrm{a}$ & $2.70 \mathrm{~b}$ & $0.73 \mathrm{i}$ \\
P13 & Brașov & $2.37 \mathrm{~d}, \mathrm{e}$ & $2.04 \mathrm{f}$ & $0.51 \mathrm{j}$ \\
\hline
\end{tabular}

Note: Results represent mean of three replicates, individually analyzed. Different letters within the same column denote significant differences (Duncan test, $\mathrm{p}<0.05$ ). 
Data presented in Table 2, show the amount of flavonoids, phenolic acids and caffeic acid phenetyl ester in analyzed propolis sample. Excepting P12, in all other samples pinocembrin was found and quantified in different amounts $(0.15-2.08 \mathrm{mg} / \mathrm{g}$ propolis). Chrysin and caffeic acid phenetyl ester were found in all 13 samples, while galangin was quantified in nine from the thirteen samples. In all samples caffeic, p-coumaric and ferulic acids were identified and quantified (Tab. 2).

High amounts of CAPE were quantified in the sample with high amount of chrysin and caffeic acid (Tab. 3). No correlation between CAPE content and galangin was found, high amounts of flavonoid (galangin), does not show also high amounts of ester.

\section{CONCLUSION}

Romanian propolis posses different amounts of biologically active compounds, depending on the botanical source of the sample.

Cafeic acid phenethyl ester (CAPE) is found in high amounts in all tested propolis samples

High amounts of CAPE are correlated with high amounts of cafeic acid and chrysin

No correlation of CAPE content and geographical origin was observed, the conclusion being that CAPE as well as the other bioactive compounds, are correlated with the botanical origin of the resins collected by bees for producing propolis.

Acknowledgments. This research was made through the Partnerships in Priority Areas Programme - PN II, developed with the support of MEN - UEFISCDI, project no. 148/2014

\section{REFERENCES}

1. Bankova C, Dyulgerov A, Popov S, Evstatieva L, Kuleva L, Pureb O, Zamjansan Z (1992). Propolis produced in Bulgaria and Mongolia: phenolic compounds and plant origin. Apidologie 23:79-85.

2. Bankova V, deCastro SL, Marcucci MC (2000). Propolis: recent advances in chemistry and plant origin. Apidologie 31:3-15.

3. Bankova V, Popova M, Bogdanov S, Sabatini AG (2002) Chemical composition of European propolis: expected and unexpected results. Z Naturforsch 57c:530-533.

4. Banskota AH, Tezuka Y, Kadota S (2001). Recent progress in pharmacological research of propolis.Phytother Res 15:561-571.
5. Coneac G, Gafițeanu E, Hădărugă DI, Hădărugă NG, Pînzaru IA, Bandur G, Urşica L, Păunescu V, Gruia A (2008). Flavonoid contents of propolis from the west side of Romania and correlation with the antioxidant activity. Chem Bull “POLITEHNICA” Univ (Timişoara) 53: 56-60.

6. Croci AN, Cioroiu B, Lazăr D, Corciova A, Ivănescu B, Lazăr MI (2009). HPLC evaluation of phenolic and polyphenolic acids from propolis. Farnacia 57:1-6.

7. Garcia-Viguera C, Ferreres F, Tomas-Barberan FA (1993). Study of Canadian propolis by GC-MS and HPLC. Z Naturforsch 48c:731-735.

8. Kimoto T, Arai S, Kohguchi M et al. (1998). Apoptosis and suppression of tumor growth by Artepillin C extracted prom Brazilian propolis. Cancer Detect Prev 22:506-515.

9. Lin HP, Lin CY, Huo C, Su LC, Chuu CP (2012). Anticancer effect of caffeic acid phenethyl ester. Pharmacologia 3:2630 .

10. Lotfy M (2006). Biological activity of Bee propolis in health and disease. Asian Pac J Cancer Prev 7:22-31.

11. Marcucci MC (1995). Propolis: chemical composition, biological properties and therapeutic activity. Apidologie 26:83-99.

12. Marcucci MC, Ferrerez F, Custodio AR, Ferreira MMC, Bankova VS, Garcia-Viguera C, Bretz WA (2000). Evaluation of phenolic compounds in Brazilian propolis from different geographic regions. Z Naturforsch 55c:7681.

13. Marcucci MC, Sawaya ACHF, Custodio AR, Paulino N, Eberlin MN (2008). HPLC and ESI-MS typification: New approaches for natural therapy with Brazilian propolis. Scientific evidence of the Use of Propolis in Ethnomedicine Transworld Research Network, Kerala, India; 33-54.

14. Mărghitaş L (2005). Albinele şi produsele lor, Editura Ceres, Bucureşti.

15. Mărghitas LA, Dezmirean DS, Bobiş $O$ (2013). Importand Developments in Romanian Propolis Research. Evid Based Complem Alt Med, 1:2013 DOI:10.1155/2013/159392

16. Markiewicz-Żukowska R, Car H, Naliwajko SK, Sawicka D, Szynaka B, Chyezewski L, Isidorov V, Borawska MH (2012). Ethanolis extract of propolis, chrysin, CAPE inhibit human astroglia cells. Adv Med Sci 57, doi 10.2478/v10039-0120042-6

17. Nagy M, Grancai D (1996). Colorimetric determination of flavanones in propolis. Pharmazie 51:100-101.

18. Omene CO, Wu J, Frenkel K (2012). Caffeic Acid Phenethyl Ester (CAPE) derived from propolis, a honeybee product, inhibits growth of breast cancer stem cells. Invest New Drugs 30:1279-1288.

19. Oršolic N, Terzić S, Mihaljević Ž, Šver L, Bašić I (2005). Effects of local administration of propolis and its polyphenolic compounds on tumor formation and growth. Biol Pharm Bull 28:1928-1933.

20. Popova M, Bankova V, Butovska D, Petkov V, NikolovaDamyanova, Sabatini AG, Marcazzan GL, Bogdanov S (2004). Validated methods for the quantification od biologically active constituents of poplar-type propolis. Phytochem Anal 15:235-240. 